This item was submitted to Loughborough's Research Repository by the author.

Items in Figshare are protected by copyright, with all rights reserved, unless otherwise indicated.

\title{
Life after regions? The evolution of city-regionalism in England
}

PLEASE CITE THE PUBLISHED VERSION

http://dx.doi.org/10.1080/00343404.2010.521148

PUBLISHER

Routledge (@ Regional Studies Association)

VERSION

AM (Accepted Manuscript)

LICENCE

CC BY-NC-ND 4.0

REPOSITORY RECORD

Harrison, John. 2019. "Life After Regions? the Evolution of City-regionalism in England". figshare. https://hdl.handle.net/2134/6601. 
This item was submitted to Loughborough's Institutional Repository (https://dspace.lboro.ac.uk/) by the author and is made available under the following Creative Commons Licence conditions.

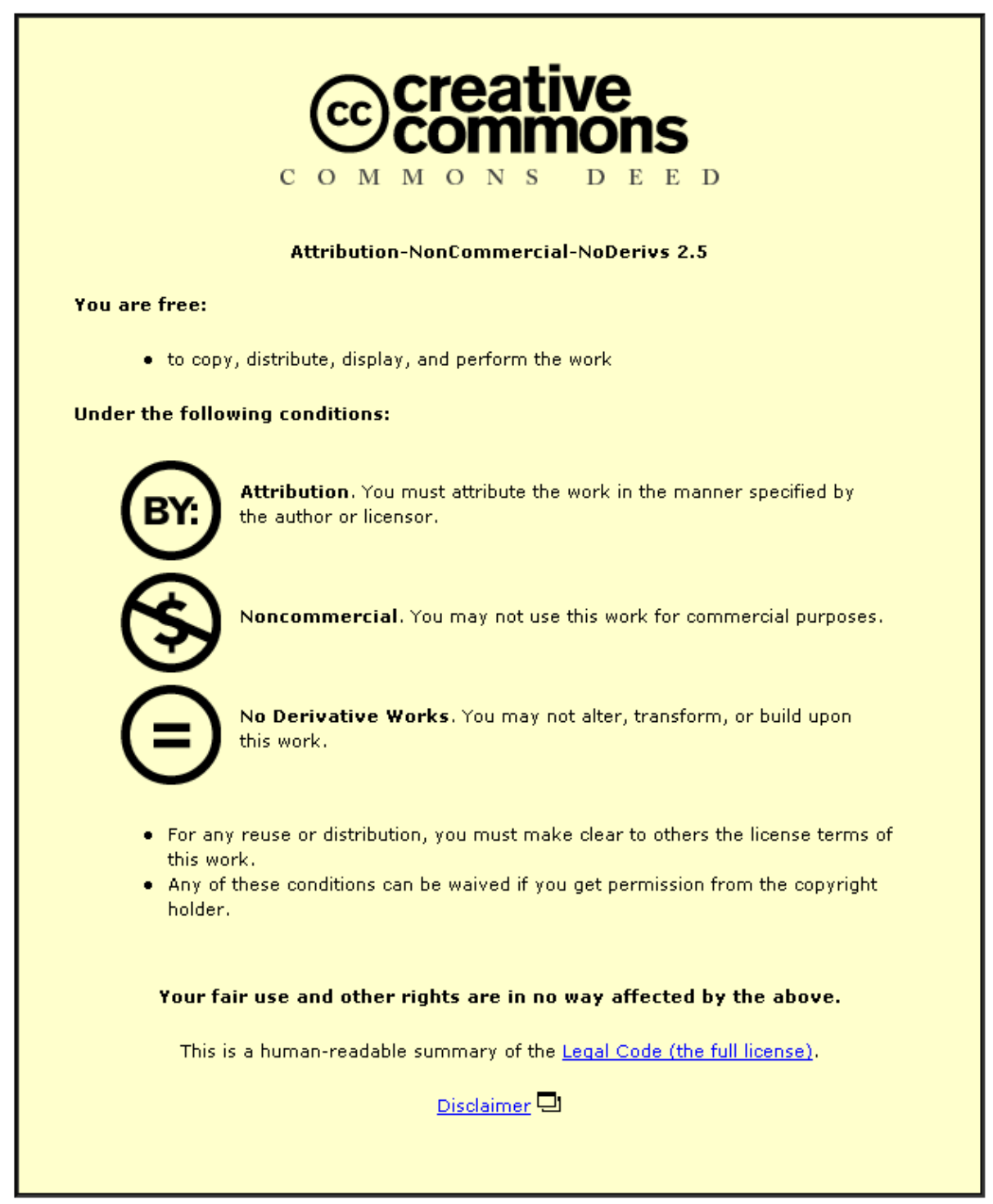

For the full text of this licence, please go to: http://creativecommons.org/licenses/by-nc-nd/2.5/ 


\title{
LIFE AFTER REGIONS? THE EVOLUTION OF CITY-REGIONALISM IN ENGLAND
}

\author{
John Harrison \\ Department of Geography, Loughborough University, Loughborough, Leicestershire, United \\ Kingdom, LE11 3TU \\ j.harrison4@lboro.ac.uk \\ Staff Page http://www.lboro.ac.uk/departments/gy/staff/gyjh/index.html \\ Personal Website http://www-staff.lboro.ac.uk/ gyih2/
}

Paper accepted for publication in Regional Studies 


\section{Abstract}

This paper examines the evolving pattern of city-regional governance in England. Following the demise of English regional policy in 2004, city-regions have come to represent the in vogue spatial scale amongst policy elites. The result has been a proliferation of actual and proposed policies and institutions designed to operate at a, variously defined, city-regional scale in England. Nevertheless, attempts to build a city-regional tier of governance have been tentative and lacking coherence. Alongside this city-regions are to be found emerging alongside existing tiers of economic governance and spatial planning. Arguing that what we are witnessing is not 'life after regions' but life with (or alongside) regions, the analysis presented argues that to understand why contemporary state reorganisation results in a multiplication of the scales economic governance and spatial planning we must recognise how the state shapes policies in such a way as to protect its legitimacy for maintain regulatory control and management of the economy. The final section relates these findings to wider debates on state rescaling and speculates on the future role of transition models in sociospatial theory.

Key words City-region; governance; England; devolution; state rescaling; transition models.

JEL codes $\quad$ 018; R10; R58 


\section{LIFE AFTER REGIONS? THE EVOLUTION OF CITY-REGIONALISM IN ENGLAND}

"The rescaling of state power never entails the creation of a 'blank slate' on which totally new scalar arrangements could be established, but occurs through a conflictual 'layering' process in which emergent rescaling strategies collide with, and only partially rework inherited landscapes of state scalar organization" (BRENNER, 2009, p.134).

"The trend - geographically uneven as it is - towards competitive city-regionalism is best understood as representing an on-going, dynamic, and conflict-ridden politics of and in space (which, in turn, is 'scaled' in a variety of ways) rather than a smooth switch to a postnational era of capitalist territoriality" (JONAS and WARD, 2004, p.2134).

\section{INTRODUCTION: LIFE AFTER REGIONS?}

November $4^{\text {th }} 2004$ signalled the death knell of attempts by the UK Labour Government to build a regional tier of governance in England. Having successfully established an elected parliament in Scotland, elected assemblies in Wales and Northern Ireland, an assembly with elected mayor in London, and (to work alongside Government Offices for the Regions) regional development agencies (RDA) and indirectly-elected regional assemblies in each of the eight English regions, the final piece in Labour's post-1997 Devolution and Constitutional Change jigsaw was to see directlyelected regional assemblies (ERA) established in England: a proposal rejected by $78 \%$ of voters in the only referendum held in North East England. Nevertheless, as the door closed on plans to 
establish elected regional governance, the door to a framework of city-regional governance opened.

With England remaining 'the gaping hole' in the UK's devolution settlement (HAZELL, 2000), the search for an alternative solution saw a host of potential solutions afforded a political hearing, including, calls for an English Parliament, English votes on English laws, English independence, strengthened local government, elected mayors, a return to ERAs in the future, regional ministers, and city-regions. Of these, city-regions captured the political imagination, and since 2004, the UK government's deepening engagement with city-regions has culminated in a series of policy measures designed to operate at a, variously defined, city-regional scale. This includes the Northern Way growth initiative, comprising eight city-regions each with their own city-region development programme (OFFICE OF THE DEPUTY PRIME MINISTER (ODPM), 2004); City Development Companies, city or city-region wide economic development companies designed to drive economic growth and regeneration (COMMUNITIES AND LOCAL GOVERNMENT (CLG), 2006a); Multi Area Agreements, designed to enable local authorities to engage in more effective cross-boundary working across the economic footprint of an area (CLG, 2006b); and most recently, statutory cityregions (HM TREASURY, 2009). Nevertheless, the rescaling of state power to city-regions is proving a complex, multi-layered and fluid process: a situation not aided by the UK government's continuing ambivalence towards devolution in general, and the merits of English regionalism in particular.

This paper analyses the evolving pattern of city-regional governance in England since 2004. It outlines the evolution of new thinking about city-regions in theory and policy, before examining the development of those initiatives which have contributed most to the evolving framework of city-regional governance in England. It also draws on insights from thirty interviews undertaken in 
2008 with inter alia government ministers, councillors, senior executives, and mid-ranking practitioners. With the exception of one, all interviews were recorded, fully transcribed and coded. Quotes are used here to capture the key points of concern expressed. Throughout the discussion, the aim is to demonstrate how the 'smooth transition' implied in the theoretical and policy rationale for city-regions overlooks and masks the role of politics that has a key role in shaping the outcome of rescaling processes. The analysis suggests that while the space for city-regions has expanded, the build up of city-regional governance adds to an already congested institutional landscape, such that the evolution of city-regionalism is, I suggest, a rather typical endeavour with regards governance - a process which adds to, rather than reforms, extant institutional arrangements. Arguing that what we are witnessing is not after all 'life after regions' but life with, or alongside, regions, the final section concludes by relating these findings to wider debates on state rescaling and speculates on the shape of future debate around the emergence of new scales of state governance.

\section{THE CITY-REGIONAL DEBATE}

\section{Theoretical rationale for city-regions}

The city-region concept has been rejuvenated as part of a wider 'new regionalist' literature documenting how in the era of globalization place-based and site-specific scales of intervention can both anchor and nurture nodes of dense economic, social and political activity. Against the backdrop of accounts heralding the transition to a 'borderless' world made up of transnational flows, the new regionalism appropriates how, by focusing on heterodox and endogenous ways of doing economic development alongside supply-side innovation strategies, actors can capitalise on 
the increasingly localised agglomeration and intense clustering of socioeconomic activity. For the most part, this is helping regions and cities prosper in globalization.

Informed by the sustained prosperity enjoyed by select regional economies in North America (Silicon Valley) and Western Europe (Baden-Württemberg, Emilia-Romagna, Rhone Alps, South East England), theory converged in the 1990s around the notion that regions represented the only scale through which order could be re-established following the collapse of the nationally configured Fordist-Keynesian accumulation regime and mode of regulation (SCOTT, 1998; STORPER, 1997). Lauded for its pioneering research in deciphering the new politics of economic development with transitions in the regulation and governance of capitalism and its territorial configuration, the orthodoxy surrounding new regionalist thinking gave rise to claims that we were now living in a 'regional world', where regions - not nation-states - are the fundamental building blocks of an increasingly post-national and globally interconnected modern world (STORPER, 1997). Not surprisingly, these accounts sparked a flurry of activity as policymakers sought to accelerate their region's path to economic competitiveness by transferring responsibility (authority) over socioeconomic decision-making and policy implementation to regional institutions, frameworks and supports. However, the recognition that the re-emergence of regions is coinciding with the resurgence of another territorial form, the city, is seeing (many of the same) authors now claim it is city-regions which are coming to function as the basic motors of the global economy (SCOTT, 2001a/b; STORPER and MANVILLE, 2006).

In the early stages of globalization the prospects for cities looked bleak. Over the period of the long post-war boom, cities across the United States and Western Europe prospered from Fordist mass-production and its unquenching demand for inputs and its reliance on a deep pool of local labour. However, the demise of Fordism left many cities on the verge of bankruptcy. Under 
threat globally from increased foreign competition, capital mobility and labour migration, and undermined locally by labour-management disputes and stagflation, by the mid-1970s cities on both sides of the Atlantic had become a serious drag on national economies. For the next two decades the consensus was that advances in technology and communication were inducing an era of global deconcentration, and with that, a diminishing role for cities. Yet while it is certainly the case that these new technologies extended our capacity to interact across space, the propensity of economic activity to coalesce in dense clusters/agglomerations provides mounting evidence that alongside select regions, a distinctive group of cities, i.e. metropolitan clusters of socioeconomic activity, are forging ahead as important staging/command posts in the new global economy (CHESHIRE, 2006; OECD, 2007; SCOTT, 2008).

Today, for the first time, more than half the world's population live in cities (UNFPA, 2007). More importantly, this urbanization is seeing the functional economies of large cities (the so-called 'economic footprint') extend beyond traditional boundaries to capture physically separate but functionally networked cities and towns in its surrounding (regional) hinterland. To give three pertinent examples: the city population of Tokyo is 12.8 million but the metropolitan population is 31.7 million, for New York City it is 8.3 and 29.9 million, and in London it is 7.6 and 21 million respectively'. From this we can clearly see how despite a resurgence of cities in globalization, in a number of respects the city (as traditionally conceived) is becoming an outdated entity, no longer adequately reflecting the underlying structure of how social and economic activity is organised. For many this new urban spatiality is best captured by the concept of the city-region, which, as PARR (2005, p.556) articulates, is seen as "comprising two distinct but interrelated elements: the city (sometimes a regional or national metropolis), possessing some specified set of functions or economic activities; and a surrounding territory, which is exclusive to the city in question". In 
particular, attention is now directed towards a select number 'global' city-regions, which, extending the logic that sees global cities defined by their external linkages (SASSEN, 1991), are defined in terms of their external and internal linkages (SCOTT, 2001a).

Yet for all the convincing arguments the lack of a commonly accepted definition for the city region remains a major concern. For instance, TEWDWR-JONES and McNEILL (2000, p.131) define the city-region as "a strategic and political level of administration and policy-making, extending beyond the administrative boundaries of single urban local government authorities to include urban and/or semi-urban hinterlands". However, for SCOTT (2001b, p.814) city-regions constitute "dense polarised masses of capital, labour, and social life that are bound up in intricate ways in intensifying and far-flung extra-national relationships. As such, they represent an outgrowth of large metropolitan areas - or contiguous sets of metropolitan areas - together with surrounding hinterlands of variable extent which may themselves be sites of scattered urban settlements". As for the UK government the city-region is "a functionally inter-related geographical area comprising a central, or core city, as part of a network of urban centres and rural hinterlands. A little bit like the hub (city) and the spokes (surrounding urban/rural areas) on a bicycle wheel" (ODPM, 2005). So despite a resurgence of interest in city-regions, it is something of a truism to say the concept remains an 'object of mystery' (HARRISON, 2007).

Nevertheless, the assimilation of city and regionalist thinking has given rise to a new cityregional orthodoxy in political-economic theory (HARRISON, 2007). Moreover, the presentation of city-regions as 'windows of locational opportunity' (SCOTT and STORPER, 2003) has sparked a new orthodoxy in political praxis, with the task of devising city-regional policies now firmly established as an officially institutionalised task throughout North America and Western Europe, along with large parts of Pacific Asia and Latin America. The UK (especially England) is no exception to this: 
since 2004, policymakers have increasingly cast 'envious eyes' towards those cities prospering at the heart of regional zones of the Atlantic, European and Pacific growth economies (KELLY, 2006; ODPM, 2006b). With this in mind the next section provides some necessary context on how the transition to city-regions has been presented as a 'smooth switch' by the UK Government in England, before the second part look at some of the broad logics and mechanisms which underpin the policy rationale for city-regions.

Policy rationale for city-regions (illustrated by the case of England)

In the period 1997-2004 the new Labour Government's vision of creating economically strong cities and regions was pursued with distinctly separate 'urban' and 'regional' policies. Urban policy focused on revitalising cities through initiatives aimed at the revival of citizenship, democratic renewal, and community involvement, with particular spatial focus on the inner city and eight core cities - Birmingham, Bristol, Leeds, Liverpool, Manchester, Nottingham, Newcastle and Sheffield plus London, where disparities are at their most. Regional policy, in contrast, was designed to build a framework of regional governance in England to complement the institutional developments taking place in Scotland, Wales, Northern Ireland and London. Duplicating what we have seen in theory, only recently has the link between cities and regions, urban and regional policy been made explicit.

The current case for city-regions can be traced back to 2000 and the publication of a pamphlet entitled 'Is there a "missing middle" in English governance?' (NEW LOCAL GOVERNMENT NETWORK, 2000). With all the policy hubris surrounding the newly established RDAs and the government's commitment to democratising regional governance, this pamphlet cut a lone voice, 
arguing that if the UK government was serious in its intention to devolve authority from the centre, especially in fields related to economic development, it should consider whether city-regions provided a more appropriate scale for policy integration and delivery than regions. At the time this was perhaps not surprisingly considered superfluous to the requirements of the regionalist agenda. But with the regional agenda reaching its nadir in 2004, the case for city-regions steadily gained momentum as an eclectic group, comprising academics, think tanks, and policy analysts successfully won over key government officials and departments. Their success was evidenced by the venerable potpourri of pamphlets, articles, policy statements, briefings, blogs, and media sound bites which flooded into the public domain, broadly supporting and stressing an appetite for greater devolution of authority from the centre and the role that city-regions could potentially play in that process (INSTITUTE FOR PUBLIC POLICY RESEARCH, 2006; KELLY, 2006; LOCAL GOVERNMENT ASSOCIATION, 2006; NLGN, 2005; ODPM, 2006a; WORK FOUNDATION, 2006). Evidence of their influence in government can be seen in the 'Devolving Decision Making - Meeting the Regional Economic Challenge' documents published by HM Treasury (finance ministry) in 2004 and 2006:

"We recognise the need to evolve our approach further to ensure that regional and local institutions have the capability, capacity and confidence to overcome regional economic disparities. Increasing institutional flexibility around targets, funding and central guidance, tied to stronger accountabilities and performance incentives, will help national, regional and local institutions work better together. The Regional Development Agencies, in particular, have an excellent understanding of what is needed to drive economic growth in the regions." Devolving Decision Making: 2 - Meeting the Regional Economic Challenge: Increasing Regional and Local Flexibility (HM TREASURY, 2004, foreword) 
"Cities represent the spatial manifestations of economic activity - large, urban agglomerations in which businesses choose to locate in order to benefit from proximity to other businesses, positive spillovers and external economies of scale. This document sets out how successful cities can contribute to competitive regions ... [and] extends the analysis and understanding of the economic role of cities and regions in lifting regional and national growth, and tackling disparities between places. It examines the drivers of, and constraints on, the economic performance of cities. It identifies the policy challenge in enabling English cities to build on recent economic growth, improve economic performance and catch up to international counterparts." Devolving Decision Making: 3 - Meeting the Regional Economic Challenge: The Importance of Cities to Regional Growth (HM TREASURY, 2006, p.1)

Clearly indicative of a shift in government policy from regions in 2004 to cities and regions in 2006, this suggests city-regions were a seed germinating under the canopy of Labour's regionalisation agenda, only able to grow and flourish once the canopy which previously concealed them was cut back and the policy light allowed to shine through. But the question on many people's lips was why, having been left with a bloody nose from seven-years of ultimately unsuccessful endeavour to build a framework of regional governance, did the Labour Government suddenly puts its faith in cityregions? To answer this question requires us to look at some of the broader logics and mechanisms which underpin the policy rationale for city-regions.

While supporters of city-regions would rightly direct attention to the strong theoretical rationale for city-regions at this point, the first and most obvious driver underlying the policy rationale for city-regions is, however, the failure of previous state spatial strategies. Failure here 
refers to the trial-and-error search to find a new spatio-temporal fix for capitalism ever since the collapse of the nationally-configured Fordist-Keynesian institutional compromise some four decades ago. In the most recent past, regions were seen by many to represent capitalisms new spatio-temporal fix. But ultimately, as critics argued, it was only ever a temporary resolution to the crisis of capitalism and one which was centrally orchestrated to enable the state to maintain its legitimacy for managing the economy (JONES, 2001). In England, with all the regional eggs placed in the ERA basket the referendum result signalled the demise of Labour's post-1997 regional policy and triggered a substantial government rethink on subnational governance in England - or to put it another way, the search for a new spatial/scalar fix (HM TREASURY et al, 2007). Stated most bluntly in the government's own inquiry into 'Is there a Future for Regional Government?' the "very public failure" of this project meant "a new regional policy was required" (CLG, 2007a, p.3). Interesting to note was how this inquiry quickly dispensed with probing future directions for Labour's regional policy, refining its terms of reference to two key questions: How does the current system of regional governance actually work? What role would city-regions play in the future development of regional policy? Supported by the strong theoretical rationale for city-regions, but ultimately sparked by the failure of previous state spatial strategies to manage the inherent contradictions of capitalism, the focus of England's new regional policy was to be city-regions.

Second, there remains a strong belief in the benefits of devolution and decentralisation. This is particularly true in Europe where the broad trend is to devolve activity - however grudgingly - to lower levels of governance according to the principle of subsidiarity, with city-regions the latest beneficiary of this principle. Where England is slightly out of step with its European neighbours in this regard is that albeit it has created what appear to be similar institutions, frameworks, and supports for devolving activity to subnational tiers of governance, the amount of authority and 
powers actually devolved has often been much less. This is despite some efforts by the Labour Government to devolve economic development powers from the centre through its 'localist' and 'regionalist' agendas. Key initiatives from the past decade, for example, the creation of Urban Regeneration Companies and Regional Development Agencies, are symptomatic of policies championed to be devolving power to the local and regional levels respectively. But despite rhetorical commitments to devolution, these and other related initiatives have been circumscribed by central government directives, targets, and limited control over funding. Conceptualised as the state's tendency towards 'centrally orchestrated localism' (JONES and WARD, 2002) and 'centrally orchestrated regionalism' (HARRISON, 2008), it is something of a truism to say initiatives launched under Labour's urban and regional programme have appeared more as mechanisms to facilitate central government intervention than to promote autonomous local and regional action. Albeit perhaps more evident in England than other contexts given the lack of authority and powers actually devolved, as RODRÍGUÉZ-POSE and GILL (2003) found in their analysis of global trends in devolution it is important to note this politics of rescaling cannot be treated as an isolated phenomenon ${ }^{\mathrm{ii}}$.

The third point to note is the politically thorny issue of regional disparities. For much of the 'new regionalist' orthodoxy centres on the claim that the decentralisation of socioeconomic decision-making and associated policy implementation to regional-level institutions, frameworks and supports can help build economically competitive, yet social inclusive, regions. In Europe this fuelled, and is consistent with, the European Commission's 'balanced competitiveness' agenda which aims to bring up lagging metropolitan areas to a common standard without damaging the position of leading cities and regions. Now although in England the Labour Government devoted more attention to regional disparities than their previous Conservative counterparts they have 
remained relatively insensitive to the geographies of uneven development and its manifestation in England's North-South divide. Constantly at pains to stress their continued commitment to the Regional Economic Performance Public Service Agreement - to "Make sustainable improvements in the economic performance of all English regions and reduce the persistent gap in growth rates between the regions" (HM TREASURY, 2007 emphasis added) - Labour have fallen far short of this target. All the evidence points towards the continuation of a trend which has seen regional disparities increase steadily over the past thirty years (DORLING et al., 2008). Confirming MORGAN's (2002, p.800) prophecy that "it is comical in the extreme to think that New Labour's modest regional policy package can in any way reverse the north-south divide", it also kept the pressure on government ministers to mitigate a perception that Labour had deserted its traditional bastions and adopted a southern bias. More broadly, it is worth noting that this concern with 'balanced competitiveness' is a particularly strong driver underpinning the development of European Metropolitan Regions in Germany (HARRISON and GROWE, 2010) alongside recent developments in Italy (GONZALEZ, 2010).

Fourth, there is general recognition that the best performing cities are those where local government boundaries more closely match the functional geography of the local economy (CHESHIRE and MAGRINI, 2009). In short, if regions are seen as too large to tackle the issues facing individual urban economies then existing city authorities are too small. Again to put this into some context, in England the city of Manchester has 450,000 residents out of a metropolitan population of over 2.5 million; Newcastle has 270,000 residents out of a metropolitan population of 800,000 ; and Nottingham has 290,000 residents out of a metropolitan population of 670,000 . England's cities are in effect under-bounded and like most, if not all, cities worldwide they are requiring of new governance arrangements to fit policies to the 'real' geography of cities. 
Related to this, fifth, competition not collaboration is traditionally the determining factor in relations between neighbouring local authorities and municipalities. In England this is particularly acute because most urban areas still receive approximately $80 \%$ of their funding - with conditions from the centre, while institutional incentives work against cross-boundary policy co-ordination and integration. For example, local authority performance has, until recently, been measured and managed in isolation, with local politicians and officials standing to gain considerably more by delivering services within their borders as opposed to co-ordinating activities across a wider urban

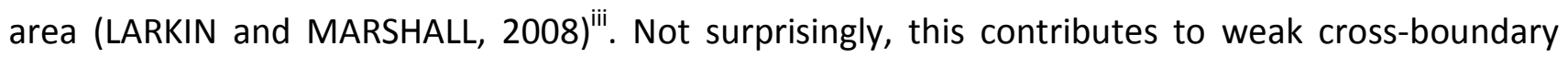
urban governance, poor horizontal coordination and a lack of policy integration.

Finally, sixth, alongside economic governance city-regions are fast emerging as an important space for spatial planning. Here it now acknowledged that spatial planning is increasingly conducted outside the formal system of practices of subnational 'planning' (local and regional) within so-called 'soft spaces' (HAUGHTON et al., 2010). Characterised by their 'fuzzy boundaries' and sometimes fuzzy scales of policy and governance arrangements, the emergence of these 'soft spaces' of spatial planning is a reflection on the fundamental problem of seeking to contain growth in formal structures of territorial governance. This is most clearly evidenced by the 'bewildering array' of 'unusual regions' - so-called because they do not relate to any administrative, territorial boundaries (DEAS and LORD, 2006) - emerging principally, though not exclusively, in Europe. Here new interregional, intercity, and transnational collaborative initiatives in spatial planning are most closely associated with the emergence and institutionalisation of cross-border regions (PERKMANN, 2007; JOHNSON, 2009), European Metropolitan Regions (BLOTEVOGEL and SCHMITT, 2006), and polycentric mega-city-regions (HALL and PAIN, 2006), many of which cut across the familiar 
territorial map of the NUTS II (Nomenclature of Territorial Units for Statistics) administrative regions.

In England, this is most clearly articulated in the four growth areas identified by the UK Government as part of its $£ 22$ bn Sustainable Communities Plan to accommodate economic success and create 'sustainable communities' within the London and South East region (ODPM, 2003). Cutting across regional and other administrative boundaries, the policy and governance arrangements developed for Ashford, the Thames Gateway, Milton Keynes and the South Midlands, and the London-Stansted-Cambridge-Peterborough corridor, are noteworthy given that none share boundaries with other statutory bodies (ALLMENDINGER and HAUGHTON, 2009). Appearing above all in the South East, the shift towards planning in terms of 'soft spaces' can also be seen as a trigger for city-regionalism outside the South East with the establishment earlier this year of the Atlantic Growth Strategy in North West England a prime example. A unique collaboration between the Manchester and Liverpool city-regions, the Atlantic Gateway constitutes a $f 50$ billion framework to enable the creation of 250000 new jobs and build 400000 homes by 2030. Branded as the 'Thames Gateway of the North' the ambitious aim of the Atlantic Gateway is to create a growth area to rank alongside Europe's strongest metropolitan economies (NORTHWEST DEVELOPMENT AGENCY, 2010).

When presented together, the theoretical and political rationales provide a strong case for city-regions and have given momentum to re-orienting political-economic activity to this scale. In England, HM TREASURY (2006, p.13) admitted as much, proclaiming that "there is significant empirical evidence to suggest that the co-ordination of economic policies across the city-region is conducive to economic performance", while similar logic has been used by the DEPARTMENT OF COMMUNITIES AND LOCAL GOVERNMENT (CLG)(2006b, p.73) to argue how "further devolution 
needs to encourage and reinforce this co-ordination and collaboration and so ensure maximum impact by better aligning decision-making with real economic geographies such as city-regions". Echoing much of what was said at the behest of regions ten years previous (REGIONAL POLICY COMMISSION, 1996), city-regions were earmarked as the latest beneficiary of the reterritorialisation of economic development policy in England.

In the same way the White Papers Building Partnerships for Prosperity (DETR, 1997) and Your Region, Your Choice (CABINET OFFICE, 2002) dominated Labour's first and second terms in office, the Review of Sub-National Economic Development and Regeneration (SNR) has defined Labour's third term (HM TREASURY, 2007). Announced at Budget 2006, the SNR fulfilled two purposes: first, prompted by the failure to establish elected regional assemblies, the review considered the efficacy of measures the government put in place since 1997 to improve subnational economic development and tackle pockets of deprivation; and second, responding to the groundswell of support for city-regions, the review amounted to Labour's attempt to smooth out the transition to a new phase of devolved politics in England by: (i) simplifying the regional tier; (ii) creating an opportunity for city-regions to bubble-up voluntarily; and (iii) giving local authorities more of a role in economic development. What is not clear is taking these theoretical positions and converting them into reality on the ground.

From regions to city-regions? Facing up to the governance conundrum

Underpinning the theoretical and policy rationale for city-regional governance is a recognition that processes of global economic integration and accelerated urbanism - the defining features of globalization - are serving to make traditional planning and policy strategies 'increasingly 
inadequate' (SCOTT, 2001a). In other words, although city-regions have been identified as a new scale of urban organisation, the pace of change - particularly in relation to their unrelenting expansion in size, scale, and number - means these pivotal social formations are increasingly reliant upon outdated and inadequate institutional structures, frameworks and supports. Despite this, the academic and policy rhetoric summarised above is one which often implies that the trend towards competitive city-regionalism involves a smooth transition to a new era of postnational territoriality (WARD and JONAS, 2004). However, this downplays the extent to which politics plays a key role in orchestrating the strategic development of city-regions.

As a number of critics have argued, issues of governance are increasingly to the fore in cityregional debates with suggestions that those who theorise city-regions as key to economic and social revitalisation are often guilty of overplaying, first, the drawing down of regulatory authority and territorial control from sovereign nation-states, and second, the smooth transition from regions to city-regions (HARRISON, 2007). On the former, the claim that city-regions are "increasingly free from regulatory supervision on the part of nation-states" (SCOTT, 2001a, p.4) is challenged by those who, drawing on experiences in different geographical locations (e.g. HARRISON, 2007 on England; McGUIRK, 2007 on Sydney, Australia), argue the relative decline in the power of the nation-state vis-à-vis the emergent power structures of city-regions is an argument whose "empirical referents are limited to a select group of 'global' city-regions" (JONAS and WARD, 2007, p.172). Meanwhile on the latter, it is something of a truism to say that transition models, where one 'new' model is deemed to have replaced the 'old' outdated model, overstate how new the 'new' model actually is, and the extent to which the 'new' model has replaced the 'old' one. In the case of urban and regional governance it has become increasingly tempting to overlook the reality whereby: (i) in many cases 'new' agencies actually represent a 'scalar amplification or 
contraction' of previous entities (LORD, 2009); and (ii) 'new' governance arrangements often 'sit alongside' rather than replace extant institutional frameworks and supports (HARRISON, 2010).

It is this less-than-reassuring context that propels JONAS and WARD $(2007, p .170)$ to suggest what is missing in city-region research is the 'politics of city-regionalism', one that examines "the particular ways in which state activity and politics have been rescaled at, around, and within cityregions". With this in mind, it is important to try and understand why certain models, strategies, policies and institutions emerge, and in the way they do. But more than this, it is increasingly important to try and understand why when the rhetoric shifts some models, strategies, policies and institutions endure, others are reworked and rescaled, while others simply disappear. Only then, it is argued, can we really begin to analyse the kind of city-region development that is occurring in different contexts, and crucially, by whom and for whom that strategic development of city-regions is being developed. Conscious of these debates, the remainder of this paper offers an initial assessment of England's own particular brand of 'new city-regionalism' and related efforts to build city-regional governance.

\section{BUILDING CITY-REGIONAL GOVERNANCE IN ENGLAND}

The evolving debate on city-regional governance has provided the backdrop for a number of institutional developments since 2004: the Northern Way, City Development Companies, MultiArea Agreements, and statutory city-regions. But while it is now widely accepted that England is seeking greater engagement with assumptions that city-regions are competitive economic territories par excellence, Labour's ambivalence towards devolution is resulting in a 'thin' approach 
being adopted, where new city-regional institutions, frameworks and supports are adding to an already congested institutional landscape.

\section{The Northern Way}

Since its launch in February 2004, the Northern Way has been the subject of considerable attention $^{\text {iv }}$. Developed in response to criticisms that the national Sustainable Communities Plan focused on the problems, not the opportunities, posed by the North of England (ODPM, 2003), the Northern Way was formed as a partnership between the three northern RDAs to "establish the North of England as an area of exceptional opportunity, combining a world-class economy with a superb quality of life" (NORTHERN WAY STEERING GROUP (NWSG), 2004, p.5). Setting out to change perceptions of the North/South divide, headlines were grabbed by the bold claim that the Northern Way would help "close the $£ 30$ bn prosperity gap between the North of England and the UK average by 2025" (ibid.). The proposed solution: a growth strategy based on eight interacting, but hierarchically differentiated, city-regions - Central Lancashire, Hull and Humber Ports, Leeds, Liverpool, Manchester, Sheffield, Tees Valley, and Tyne and Wear.

In the vanguard of endeavours to build a framework of city-regional governance, the Northern Way is indicative of the new city-regionalist orthodoxy in action. First, city-regions are clearly identified as the drivers of the North's economy. Second, the emphasis is on the important internal and external linkages of city-regions. This is reflected in (i) the top priority being transport and the need to improve connectivity within and between the North's city-regions, between the North and the rest of the UK, and internationally; (ii) the distinct 'taglines' adopted by each cityregion (e.g. Leeds' aim to 'improve city-regional, pan-regional and international connectivity'); and 
(iii) how funding is allocated through the $f 100 m$ Northern Way Growth Fund, which (breaking with the Keynesian model of spatial redistribution) has the principal aim of improving connection and collaboration between city-regions and internationally. Third, the target of bridging the f30bn prosperity gap in this way signals a shift from promoting balanced urban and regional development to policies designed to position major cities/city-regions within global circuits of capital. Illustrative of this, and normatively charged claims relating to how less illustrious city-regions might themselves become 'winners' in the global economy, Northern Way city-regions are seen to "have considerable potential to perform a similar role, in the north, to that played by London within southern England's 'super-region'” (ODPM, 2006a, p.7). And fourth, the Northern Way triggered the belief that English city-regionalism is a national policy for everywhere except the Southeast ${ }^{\mathrm{v}}$ : a point reinforced by the appearance of three more initiatives and strategies covering the remainder of England - The Midlands Way (spanning the East and West Midlands), The Way Ahead (covering the South West region) and Regional Cities East (in the East of England). All in all, as GOODCHILD and HICKMAN (2006, p.123) contend:

"The policy assumptions of The Northern Way conform ... to the principles of the new regionalist discourse with repeated justifications in terms of regional self-reliance and institution building, the abandonment of any attempt to steer growth from the south to the north of England and, by implication, the abandonment of efforts to reduce regional economic differentials." 
However, far from representing a smooth transition to re-territorialising economic development policy to city-regions, the Northern Way exposes contradictions and tensions in Labour's endeavour to build institutional capacity at the city-region scale.

At one level, the Northern Way is more concerned about 'the North' than it is city-regions. It was actually on the campaign trail for elected regional assemblies in early 2004 (when referendums were scheduled for all three northern regions) that the then Deputy Prime Minister, and self-styled 'governor of the regions', John Prescott, devised the Northern Way as a mechanism to dovetail the political and constitutional elements of regionalism (ERA) with the economic rationale for regionalisation (RDAs). In fact, the Northern Way as originally conceived by Prescott and his advisors was based on two urban growth corridors connecting the North's five core cities ${ }^{\text {vi }}$ - one east-west linking Liverpool, Manchester and Leeds, and one north-south linking Newcastle, Leeds and Sheffield (ODPM, 2004) - not as it appears today city-regions: only when the three northern RDAs were charged with taking forward and developing the Northern Way, and the failure to establish elected regional assemblies left the Northern Way dangerously exposed, did the spatial focus become city-regional (NWSG, 2004). Furthermore, the selection of eight city-regions owes more to political compromise than economic evidence: in addition to the five core cities initially regarded as economic assets, negotiations resulted in the inclusion of other urban/non-urban areas (Central Lancashire, Hull and Humber Ports, Tees Valley). In other words, the dovetailing of the Northern Way to the city-region agenda came about more by coincidence than grand design, and certainly in advance of a coherent and convincing evidence-base. Nevertheless, as a city-region initiative the Northern Way was heralded as "one of the most significant initiatives in regional economic policy for a number of years" (ADAMS, 2004, p.1): indicative of the blind faith in cityregions at this time. 
At another level, the Northern Way is constrained by the institutional legacy of Labour's post-1997 regional policy and the failure to fundamentally reform extant institutional structures. Most notable here is the role of RDAs. Alongside their statutory remit for regional economic development, Labour's decision to afford RDAs the lead role in the NWSG gives them additional responsibility for pan-regional and city-regional economic development. Arising from this are concerns that the Northern Way is actively constrained by the priorities already established by RDAs in their Regional Economic Strategies (HARRISON, 2010). Related to this, the operational decision to locate responsibility for delivery with RDAs means Northern Way activity is squeezed into the already busy workload of RDAs. As a result, many initiatives badged as Northern Way activity are RDA projects writ large. And as if this were not enough, that $f 50 m$ of the original $f 100$ million growth fund came from RDA budgets - a situation made worse by the government withdrawing its $f 50 \mathrm{~m}$ for 2008-11 - means the Northern Way is funded by RDA money. Unsurprisingly this leads RDAs to be evermore protective of their money, and in particular, the need for RDAs to ensure that city-regional activities deliver against their (centrally determined) regional targets.

All of which points to the Northern Way evolving more as a regional partnership than as a distinct city-region initiative. But it also raises the spectre of ever more complex governance arrangements. For the Northern Way has not replaced existing arrangements, but added to an already congested institutional landscape.

City Development Companies 
First announced in the 2006 Local Government White Paper Strong and Prosperous Communities, City Development Companies (CDC) are "city or city-region wide economic development companies formed to drive economic growth and regeneration" (CLG, 2006b, p.4). Subsequently put out to consultation in December 2006, the premise for CDCs is that international evidence (in this case from Toronto, Baltimore, Greater Washington and Stuttgart) shows the economic transformation of a city or city-region requires an arm's length organisation, distanced from local and central government (CLG, 2006a). If their architect in England, Stuart Gulliver, is to be believed, CDCs are "a high calibre organisation, obsessive about delivery and high quality, selective in where and how it operates" (GULLIVER, 2007, p.10) vii. Yet for Gulliver, CDCs are not some "all singing, all dancing, economic development agency"viii, but "rowing, steering, and cheering" organisations (ibid). Nevertheless, emerging as they did alongside the city-region initiative, the proposals for CDCs were deemed to have "given added impetus to the development of city-regions" (CLG, 2008, p.11). Since then, CDCs have been established in Sheffield, Liverpool, Hull, Newcastle-Gateshead, Plymouth, Pennine Lancashire and Cornwall, with plans in place for their creation in Derby, Leicester and Leicestershire, Greater Nottingham, and Torbay. However, the extent to which CDCs give added impetus to the development of city-regions is unproven.

At root, CDCs are not a new initiative, but an outgrowth of sub-city urban regeneration companies (URC) established following Lord Rogers' 1999 Urban Task Force report which was commissioned by the incoming Labour Government to identify the causes of urban decline in England and recommend solutions to bring people back into cities and establish a vision for urban regeneration (DETR, 1999). Certainly in the case of the first three CDCs established - Creative Sheffield, Liverpool Vision, Hull Forward - the move to create new-style city-wide or city-region wide CDCs actually pre-dates the government consultation on CDCs and Labour's interest in 
building institutional capacity at the city-region scale. The establishment of CDCs reflects a local response rooted in the desire to amplify the geographical coverage of their URC to improve effectiveness and efficiency across a wider geographical area. In other words, the government looked at what was going on organically in a number of England's core cities, captured the concept of CDCs from international evidence of what appeared to work in other successful metropolitan areas, and branded it as part of their city-region agenda. CLG even admitted as much when consulting on the role of CDCs in England:

"Sheffield City Council has built on the track records of existing bodies, including the urban regeneration company (URC), Sheffield One, to establish a new city development company, Creative Sheffield, to spearhead the economic transformation of the city. Other places have developed, or are developing, new holistic development vehicles, combining functions such as housing strategy with a wider economic role. The Government believes there is considerable potential in this approach. Economic development companies operating at the city or city-regional level are a well established concept in countries including the United States, Canada, the Netherlands and Germany" (CLG, 2007b, p.7).

This process of adding-to rather than fundamentally reforming what already exists had two knockon effects. First, as one civil servant explained in interview:

"There is an issue about at what stage does a URC become an EDC and there is a very grey area where some URCs already think that they are doing EDC stuff, which they are, but they 
also come under the URC branding at the moment. And there are discussions about are we running parallel policies, which we probably are to an extent. Now we do need to look at how we stop the confusion out there." [Civil Servant]

And second, more noticeable is how the metamorphosis of sub-city URCs into city-regional CDCs has not taken off in England (cf. LORD, 2009). Most CDCs are actually city-wide (Sheffield, Hull, Plymouth, Liverpool, Derby), while one covers two cities (Newcastle-Gateshead), one is polycentric (Pennine Lancashire), and a number are not based on cities at all (Cornwall, Torbay). In fact, the closest to a city-regional $C D C$ is Manchester, which is not officially recognised as a $C D C^{i x}$, or Nottingham, which due to the seriously under-bounded nature of the city will cover the Greater Nottingham conurbation when established.

So why has the concept of a city-regional CDC not taken off? Well as mentioned above, CDCs are not a new institution, but an outgrowth of sub-city URCs. Second, despite the policy rhetoric for CDCs being about the co-ordination of economic policies across the city-region being conducive to economic performance, their URC legacy means CDCs often remain rooted in a physical development tradition, which remains best delivered at a local level. Third, there is political unease in making CDCs too big as the more you expand the net, the chance of individual local authorities 'losing' increases. A fourth point has seen the rebranding of CDCs as Economic Development Companies (EDC) in response to widespread criticism that CDCs were "equally valid vehicle for urban and non-urban sub-regions" (CLG, 2007b, p.6). And finally, as this interviewee reflects, there is no compulsion for CDCs to be city-regional: 
"The question we are always asking is: what is the best spatial geography/scale to do economic development? Now CDCs are interesting because they were set up to answer this question. Is it city-wide? Is it city-regional? With URCs and RDAs government already thought they knew the answer." [Economic Development Officer \#1]

All points that cast doubt on the Government claim that CDCs are giving 'added impetus' to the development of city-regions. But it also raises serious doubts as to Labour's commitment to cityregions. For as one interviewee remarked, in trying to meet everyone's requirements the theoretical and policy rationale for city-regions has been lost:

"The initial thinking was about the importance of cities, and that element within Central Government which understands and is supportive of that argument of strong core cities at the heart of city-regions. CDCs were therefore seen as a real focus on the cities. Now the change to EDCs means you actually lost that. By going to consultation the Government have had to try to come up with something that meets everybody's requirements. And I think they have actually lost the plot. They have lost what the original idea was. It was about strong regions, strong city regions, and strong core cities at the heart of that. That's where CDCs really fitted." [Economic Development Officer \#2]

\section{Multi-Area Agreements}


Announced alongside CDCs, Multi-Area Agreement's (MAA) are frameworks through which adjoining local authorities work in partnership "to facilitate greater cross-boundary collaboration, particularly on key economic development issues" (CLG, 2006b, p.69). With an MAA in place, political and administrative boundaries should no longer prevent local authorities working together on policy issues such as transport, land use planning, skills and unemployment, capital investment and infrastructure provision. Moreover, they enable authorities to pool funding, resources, and targets, with agreements made between groups of local authorities, before ultimately being authorised by central government. To incentivise MAAs the government is committed to action to devolve more power and reduce barriers to delivering better outcomes in return for groups of local authorities who set out a convincing case for how they can boost economic growth and tackle deprivation and financial inequalities by working together across a functional economic area.

In the first set of MAAs signed off in July 2008, seven groups of councils and local partners sealed their commitment to work to boost economic growth across a functional economic area. These were Tees Valley (Middlesbrough), Greater Manchester, South Yorkshire (Sheffield), Leeds, South Hampshire (Portsmouth/Southampton), Bournemouth-Dorset-Poole, and Tyne \& Wear (Newcastle/Sunderland). On 12 January 2009, a second round of agreements was signed-off for Liverpool, Leicester and Leicestershire, and Pennine Lancashire. A third round saw Birmingham, Coventry and Black County, North Kent (Dartford), and West of England (Bristol) signed-off on 9 September 2009. Most recently, the Fylde Coast MAA was signed off on 15 October 2009, with others, most notably the Olympic host boroughs, expected to be signed-off in the coming months. This would take the number of agreements to fifteen, covering more than one hundred councils.

Like CDCs, MAAs are an outgrowth of an already existing initiative - Local Area Agreements $(\text { LAA })^{x}$. First introduced in 2004-05, LAAs are three-year agreements developed by local councils 
with their partners in a local strategic partnership, and then negotiated with the relevant Government Office for the Region, before being agreed and signed off by the Secretary of State. Starting with an initial 20 pilot areas, this has extended to cover all 150 upper-tier local authority areas in England. However, confusion abounded when the initial negotiation period of MAAs (up to June 2008) ran concurrent with that of new LAA agreements for 2008-11. Considerable confusion surrounded (i) whether LAAs or MAAs were the government's priority; (ii) whether they were mutually constituted for delivery and measuring performance; and (iii) why ownership of LAAs rested with a regional institution (Government Offices for the Regions) and MAAs with a government department (CLG).

MAAs also exhibit incredible spatial and scalar flexibility. Like CDCs, there is clear appetite for cross-boundary working outside the core cities and their hinterlands. Spatially, MAAs cover populations ranging from approximately 330,000 in the Fylde Coast MAA $1<5 \%$ of the North West region) through to 2.76 million in the Birmingham, Coventry and Black Country MAA ( $>50 \%$ of the West Midlands region), and areas ranging from $384 \mathrm{~km}^{2}$ (the proposed Luton and Bedfordshire MAA) to $5,716 \mathrm{~km}^{2}$ (Leeds) (RUSSELL, 2008). Unlike CDCs though, there is more appetite to have city-regional MAAs. Liverpool, Hull, Newcastle-Gateshead and Sheffield all have city-wide CDCs yet a city-regional MAA, while Birmingham, Bristol, and Leeds, who do not have a CDC, see fit to have a city-regional MAA. Yet the MAA process highlighted a new set of concerns.

Symptomatic of the growing confusion, the importance attached to city-regions diminished in the months after the SNR was published. Indicative of this was how 'city-region' was either replaced by, or became a subset of, the more politically-neutral term 'subregion' in the post-SNR literature. In the case of MAAs, for instance, the new rhetoric suggested "MAAs will allow subregions, including city-regions, to take a much more active role in leading economic development" 
(HM TREASURY, 2007, p.89), leading to complaints that Labour was losing sight of the theoretical and policy rationale for city-regions. The result is CDCs and MAAs are now implicitly city-regional at best. As one disgruntled interviewee put it to me, city-regions were becoming the proverbial elephant in the room:

"It's pathetic. The phrase 'city-regions' hardly occurs at all now. When you challenge government officials, they say 'but surely when we talk about subregions, city-regions are a part of that'. But they are more than a subset of subregions. By describing subregions generally rather than understanding the city-region connection you undermine one of the key messages about how you make urban economies work and how you join up across boundaries ... It has become a debate more about the relations between local government and regional institutions across the whole of the country and as a result the national consultation paper has had to produce a one size fits all type document. But we think some of the distinctive messages for city-regions have been lost as a consequence of that." [Senior Policy Official]

So why did Labour feel the need to water down (at worst remove) city-regions from their subnational economic development agenda? At one level, the move signalled Labour's response to growing concerns that their city-region agenda was seen as too city-centric - a case of 'picking winners'. At another level, key political advocates of city-regions in Government saw their role in change around this time. In May 2006, David Miliband went from being Minister of State for Communities and Local Government to Secretary of State for the Environment, Food and Rural 
Affairs, while in June 2007, a second cabinet reshuffle (prompted by Tony Blair's decision to stand down as Prime Minister) saw John Prescott resign his Cabinet position as Deputy Prime Minister, Ruth Kelly (who replaced Miliband as Secretary of State for Communities and Local Government) move to the Department of Transport, and Ed Balls (chief economic advisor and later Economic Secretary to the Treasury) take up the position of Secretary of State for Children, Schools and Families. All strong advocates of city-regionalism, in each case, their move removed an important cog in the engine that was driving forward the city-region agenda in Government during 2005-2006. The result saw city-regions slip off the political radar for a period of 12-18 months, only re-emerging on 24 November 2008 with the then, Chancellor of the Exchequer, Alistair Darling, announcing in his Pre-Budget Report that Government were preparing the way to announce "at least two forerunner (statutory) city-regions at Budget 2009" (HM TREASURY, 2008, p.82).

\section{Statutory City-Regions}

On 22 April 2009 at Budget 2009, Alistair Darling announced Leeds and Manchester as two forerunner statutory city-regions. The promise was of increased statutory responsibility for strategic transport issues, joint housing and regeneration boards, formal powers over education and skills, integrated city-region planning, and additional financial flexibility over capital funding. But if Labour thought naming statutory city-regions would alleviate criticism for their previous ambivalence toward city-regions they were mistaken. For the process of reaching the announcement of Leeds and Manchester as statutory city-regions was symptomatic of the confusion surrounding the evolution of city-regionalism in England. 
In March 2008, CLG and the Department for Business, Enterprise and Regulatory Reform (BERR) published Prosperous Places: Taking Forward the Review of Subnational Economic Development and Regeneration, which held out the possibility of establishing statutory city-regions, though not in those words. Instead it was suggested "there may be advantages in strengthening the statutory basis for sub-regional collaboration between authorities, including more visible leadership" (CLG/BERR, 2008a, p.9): a further indication that the term 'city-region' was being avoided where possible. Put out to consultation until 20 June 2008, the Government response announced plans to create "statutory sub-regional authorities for economic development", and these would be called Economic Improvement Boards (EIB) (CLG/BERR, 2008b, p.12). Statutory cityregions in all but name, the clear suggestion was that these would build on the existing MAA arrangements i.e. MAAs with statutory duties (what are seen as MAA+ or MAA v2.0). Where confusion set in was this announcement appeared on 25 November 2008, the day after the PreBudget Report. So there was confusion as to whether EIBs were the same or different to the forerunner city-regions announced in the Pre-Budget Report; there was more confusion when it appeared that although EIBs are expected to evolve out of MAAs "there will be no requirement for any existing arrangements to be in place" (p.13); and to add to the confusion, ElBs were almost immediately renamed Economic Prosperity Boards (EPB). In the end, all were effectively talking about 'statutory city-regions' but the confusion was symptomatic of muddled thinking in Government, and the result of calls from very different types of area to form cross-boundary agreements.

Second, by inviting prospective city-regions to put forward their case, Darling's Pre-Budget announcement sparked a five-month bidding-war between policy officials in Birmingham, Bristol, Leeds, Luton, Manchester, Sheffield and Tees Valley, all of who hoped they would be named a 
forerunner city-region at Budget 2009. In the end only Leeds and Manchester were named, a decision which added more fuel to suggestions that city-regionalism is about 'picking winners'. For having made city-regionalism open to everyone, and encouraging bids by announcing at least two forerunner city-regions, the question on most people's lips was why the government then chose not to take the option of announcing more. One possible answer is that Darling's decision was a throwback to the early days of city-regionalism in England, a return, in part, to the original conception of the Northern Way as a growth corridor between Leeds and Manchester acting as counterweight to London and the south east.

And finally, areas were bidding in the faith, rather than the knowledge, that statutory cityregions would provide real devolution. With more than a distinct sense of déjà vu, the Government outlined areas that will "potentially" be devolved, but there was no detail or commitment to the scale, scope and timeline for devolution ${ }^{\mathrm{xi}}$. Not convinced that sufficient powers would be devolved, Liverpool pulled out of the process, while Manchester threatened to walk away unless significant powers were on offer. For Leeds and Manchester, having bid more in hope than expectation, and then experienced the initial joy of becoming forerunner city-regions, their enthusiasm has been tempered as EPBs have gone through Parliament. Perhaps unsurprising given Labour's continued ambivalence towards devolution and the merits of regionalism and localism in England, the BUSINESS AND ENTERPRISE COMMITTEE (2009) were "surprised and disappointed by the lack of detail contained in the Government's proposals" (para. 67), concluding that EPBs "might be an unnecessary addition" to existing subnational organisations and strategies (para. 161). This can also be seen as the most concrete indication to date of MORGAN's $(2006, p .1)$ prophecy that the cityregion concept is in danger of becoming "simply the latest in a long line of fashionable ideas" actually becoming reality. 


\section{CONCLUDING COMMENTS: LIFE AFTER REGIONS OR FILLING IN GAPS?}

Born out of the crisis of regions, the evolution of city-regionalism in England has been a quiet but potentially significant revolution. The result has been a series of policy measures designed to rescale state power to city-regional institutions, frameworks and supports in the belief that this will position city-regions within global circuits of capital and thus deliver economic and social revitalization. However, five years on city-regionalism in England remains more like a firework display than an illuminating policy panacea, each initiative being launched with a crescendo of noise, only to sparkle for a short time, before appearing to fizzle out and fall slowly back to earth.

One theoretical question arising from this analysis is the degree to which England's brand of 'new city-regionalism' can be seen as a feature of contemporary state (re-)organization more generally. The first point to stress is what we have seen in England is not actually 'life after regions', but the emergence and institutionalisation of city-regions alongside the existing regional tier. While it is true to say that city-regions emerged to fill the policy gap left by the failed plans to establish a fully-elected tier of regional governance in England, this is not serving to replace regions as part of some zero-sum or either/or logic but is emerging as a new site and scale of state organisation alongside regions. In other words, city-regions are not replacing regions, just as city-regions and regions are not replacing the nation-state. What we are seeing is contemporary processes of state scalar (re-)organization leading to a multiplication of scales of economic governance and spatial planning as policymakers and strategists strive to do what is deemed necessary to 'win' in today's quicksilver global economy. But to really understand why contemporary state reorganisation implies the multiplication of scales we need to recognise that the underlying logic and mechanism behind these developments is the ongoing trial-and-error search for a new spatial/scalar fix for 
capitalism. Alongside this we also need to recognise that multiplication rather than replacement of spatial scales is indicative of how existing scales of policymaking continue to play a crucial role in protecting the state's legitimacy for maintaining regulatory control and managing the economy.

With this in mind, a second point to consider then is the worth and value of 'transition models' in conceptualising contemporary processes of state rescaling. Transition models are by their very nature preliminary; should we be surprised, therefore, that they are often misleading and over generalized? On this basis, it is important to recognise that transition models, while rightly critiqued as "transition fantasies of intellectuals and policymakers" (LOVERING, 1995), do still serve an important role. As BRENNER (2009) recently noted, when accomplished rigorously, transition models and general concepts are important for characterising emergent processes of state rescaling. They can also identify trends and contribute to efforts to elaborate 'big-picture' generalizations by bringing a macro-spatial and macro-historical synthesis to what appears initially to be periods of 'intense volatility' as institutional shifts, policy realignments and political struggles occur in apparent isolation and an inchoate way. Furthermore, they provoke reaction, acting as a stimulus for creative thinking and productive debates on contemporary processes of state rescaling. But on the flip side, their use as political tools to advance one way of thinking over another - in this case, to prioritise one scale (the city-region) over another (the region) - is the danger lurking within.

It is here that this paper has sought to contribute to current debates by exploring how the city-region concept is being mobilised as a political strategy and the extent to which it is transforming established formations of state scalar organisation. The analysis presented shows how despite the theoretical and policy rationales purporting a smooth transition from regions to cityregions, this endeavour to build city-regional governance in England is surrounded by a series of tensions. The first is the difficulty in defining city-regions, with much of what is branded as 'city- 
regional' bearing little resemblance to the logic and rationale for city-regions à la SCOTT (2001a) and others. Second, is the politically-charged nature of city-regions which is seeing 'city-region' replaced by, or made a subset of, the more politically-neutral concept 'subregion' in much of the policy literature. Third, is the deep ambivalence shown by the Labour government toward devolution in general and the merits of English regions and localism in particular, evidenced by city-regionalism delivering more by way of hope than expectation. And fourth, is the failure of city-regions to really emerge from the shadow of regions, with regional and national institutions maintaining a key orchestrating role in the strategic development of city-regions.

Clearly England's 'scalar messiness' results, in part, from factors at play in England - the Labour government's reluctance to undertake fundamental reforms, the centralising tendencies in UK political-economy, the failure to establish a directly accountable tier of regional governance but it is also expressive of contemporary state spatiality more generally. First, the paper offers a stark reminder that rescaling is not simply the privileging of one scale of governance (city-regions) over another (regions). In the case of England it has been shown how despite the rhetoric, rationale and logic for city-regions the city-region is not always privileged in practice, with a variety of subregional spaces developing cross-boundary governance arrangements - of which only some are city-regional. In part this is illustrative of how contemporary state rescaling is filling in the gaps between existing tiers of governance, but it can also be suggested that this demonstrates once more how the state shapes policies in ways that protect its legitimacy for maintaining regulatory control and managing the economy.

Meanwhile and related to this, second, the capacity for coordinated implementation at the city-region scale is hampered by inherited inflexibility of the state apparatus. By analysing the logic and rationale underpinning the four models of city-region governance in England it has been shown 
how Northern Way city-regions responded to the failure at that point to involve networked opportunities in economic development and the failure to establish elected regional assemblies, CDCs are a locally rooted response to the need to upscale the geographical coverage of URCs, MAAs a response to the need to increase cross-territorial as well as inter-territorial alliances, and statutory city-regions the need for more visible leadership and accountability. In many ways, the four models of city-region governance are designed to plug and/or bridge the gap left by previous ideas, policies, strategies and models. Yet for all this, they are constrained and hampered by the fragmented legacies left by the very policy initiatives they are being mobilised to replace and/or extend. If one sees those models, strategies, policies and institutions that the state reworks and/or leaves in place as there to protect its legitimacy to manage the economy then we can perhaps begin to understand why they emerge in the way they do.

The problem for the state is, as noted by HUDSON (2000) some ten years ago, the growing disjunction that now exists between the intentions and outcomes of its actions. Indeed, it is in this and the wider context of competing sociospatial relations (JESSOP et al., 2008) that JONES (2010) identifies an 'impedimenta state': "a trend for the state to become the medium and outcome of a series of economic development rationalities, which are implemented through multiple spatial strategies and projects, but their apparent incompatibility and baggage-like polity is reproducing irrationality" (JONES and JESSOP, 2010, p.28). In this and other accounts, it is not only necessary to move beyond accounts which privilege one scale over another but, in considering how the various scales of governance intersect and interact, to seek to understand the 'variation, selection, retention and institutionalisation' of ideas, policies, strategies and models. The arguments in this paper suggest that events surrounding the attempts to forge England's particular brand of cityregionalism has provided a lens through which to observe and seek to understand the variation and 
selection of various models of city-region governance (cf. FULLER, 2010). Going forward, it will be important to observe which models are retained and institutionalised given that "what seems possible for short-term co-existence of elements or events may prove impossible ... in the mediumor long-term or, alternatively, may require changes elsewhere" (JONES and JESSOP, 2010, p.30). Indeed, as fellow commentators on the subnational policy landscape in England note, "the emerging policy environment has sought to let a thousand sub-regional flowers bloom, with all the implications that follow for national and regional agencies in their anticipated roles as gardeners" (HARDING and REES, 2009, p.17) - a point which suggests this might already be happening, but also signifies the pertinence of this particular case-study among many others for trying to understand the state's most recent attempts to protect its legitimacy for maintaining regulatory control and managing the economy. 
Acknowledgements This paper draws on research funded by the British Academy (Grant Number SG-47714). Earlier versions of the paper were presented at the 2010 AAG annual conference in Washington DC and a Regional Studies Association organised seminar at CURDS, Newcastle. The author wishes to thank the organisers and audience at these events, and the editors and two anonymous reviewers for their constructive feedback. The usual disclaimers apply. 


\section{BIBLIOGRAPHY}

ADAMS J. (2004) The Northern Way. The Journal, 16 April.

ALLMENDINGER P. and HAUGHTON G. (2009) Soft spaces, fuzzy boundaries, and metagovernance: the new spatial planning in the Thames Gateway. Environment and Planning A 41, 617-33.

BLOTEVOGEL H. and SCHMITT P. (2006) 'European metropolitan regions' as a new discursive frame in strategic spatial planning and policies in Germany. Die Erde 137, 55-74.

BRENNER N. (2009) Open questions on state rescaling. Cambridge Journal of Regions, Economy and Society 2, 123-39.

BUSINESS AND ENTERPRISE COMMITTEE (2009) Regional Development Agencies and the Local Democracy, Economic Development and Construction Bill. House of Commons, London.

CABINET OFFICE (2002) Your Region, Your Choice: Revitalising the English Regions. TSO, London.

CHESHIRE P. (2006) Resurgent cities, urban myths and policy hubris: What we need to know. Urban Studies $43,1231-46$.

CHESHIRE P. and MAGRINI S. (2009) Urban growth drivers in a Europe of sticky people and implicit boundaries. Journal of Economic Geography 9, 85-115.

CLG (2006a) The Role of City Development Companies in English Cities and City Regions. CLG, London.

CLG (2006b) Strong and Prosperous Communities: The Local Government White Paper. CLG, London.

CLG (2007a) Is there a future for Regional Government? Volume I. CLG, London. 
CLG (2007b) The Role of City Development Companies in English Cities and City Regions - Summary of Responses. CLG, London.

CLG (2008) Review of Economic Assessment and Strategy Activity at the Local and Sub-regional Level. CLG, London.

CLG/BERR (2008a) Prosperous Places: Taking Forward the Review of Subnational Economic Development and Regeneration. CLG, London.

CLG/BERR (2008b) Prosperous Places: Taking Forward the Review of Subnational Economic Development and Regeneration. The Government Response to Public Consultation. CLG, London.

DEAS I. and LORD A. (2006) From a new regionalism to an unusual regionalism? The emergence of non-standard regional spaces and lessons for the territorial reorganisation of the state. Urban Studies 43, 1847-77.

DETR (1997) Building Partnerships for Prosperity: Sustainable Growth, Competitiveness and Employment in the English Regions. TSO, London.

DETR (1999) Towards an Urban Renaissance: Report of the Urban Task Force. TSO, London.

DORLING D., VICKERS D., THOMAS B., PRITCHARD J. and BALLAS D. (2008) Changing UK: The way we live now. BBC, Sheffield.

FULLER C. (2010) Crisis and institutional change in urban governance. Environment and Planning $A$ $42,1121-37$. 
GONZALEZ S. (2010) The North/South divide in England and Italy: discursive construction of regional inequality. European Urban and Regional Studies (Online First DOI: 10.1177/0969776410369044).

GOODCHILD B. and HICKMAN P. (2006) Towards a regional strategy for the North of England? An assessment of 'The Northern Way', Regional Studies 40, 121-33.

GULLIVER S. (2007) Setting up a City Development Company in Newcastle-Gateshead. 1NG, Newcastle.

HALL P. and PAIN K. (Eds.) (2006) The Polycentric Metropolis: Learning from Mega-city Regions in Europe. Earthscan, London.

HARDING A. and REES J. (2009) MAAs: making the case for integrated places, in HOPE N. (Eds.) Cities, Sub-regions and Local Alliances, pp.16-20. NLGN, London.

HARRISON J. (2006) The political-economy of Blair's 'new regional policy’. Geoforum 37, 932-943.

HARRISON J. (2007) From competitive regions to competitive city-regions: A new orthodoxy, but some old mistakes. Journal of Economic Geography 7, 311-32.

HARRISON J. (2008) Stating the production of scales: Centrally orchestrated regionalism, regionally orchestrated centralism. International Journal of Urban and Regional Research 32, 922-41.

HARRISON J. (2010) Networks of connectivity, territorial fragmentation, uneven development: the new politics of city-regionalism. Political Geography 29, 17-27.

HARRISON J. and GROWE A. (2010) From places to flows? Planning for a new 'regional world' in Germany (in preparation)

HAUGHTON G., ALLMENDINGER P., COUNSELL D. and VIGAR G. (2010) The New Spatial Planning: Territorial Management with Soft Spaces and Fuzzy Boundaries. London, Routledge. 
HAZELL R. (2000) An unstable union: Devolution and the English question, State of the Union Lecture. Constitution Unit, London.

HM TREASURY (2004) Devolving Decision Making 2 - Meeting the Regional Economic Challenge: Increasing Regional and Local Flexibility. HM Treasury, London.

HM TREASURY (2006) Devolving Decision Making 3 - Meeting the Regional Economic Challenge: The Importance of Cities to Regional Growth. HM Treasury, London.

HM TREASURY (2007) Comprehensive Spending Review. HM Treasury, London.

HM TREASURY, CLG and BERR (2007) Review of Subnational Economic Development and Regeneration. HM Treasury, London.

HM TREASURY (2009) Budget 2009. HM Treasury, London.

HUDSON R. (2000) Production, Places and Environment. Prentice Hall, London.

IPPR (2006) City Leadership - Giving City-Regions the Power to Grow. Centre for Cities, London.

JONAS A. and WARD K. (2004) Competitive city-regionalism as a politics of space: a critical reinterpretation of the new regionalism. Environment and Planning A 36, 2119-39.

JONES M. (2001) The rise of the regional state in economic governance: 'partnerships for prosperity' or new scales of state power? Environment and Planning A 33, 1185-1211.

JONES M. (2010) Impedimenta state: anatomies of neoliberal penality. Criminology and Criminal Justice 10 (in press)

JONES M. and JESSOP B. (2010) Thinking state/space incompossibly. Antipode 42 (in press)

JONES M. and WARD K. (2002) Excavating the logic of British urban policy: Neoliberalism as the 'crisis of crisis-management'. Antipode 34, 479-500.

KELLY R. (2006) Keynote Speech. Core Cities Summit, Bristol 26 June.

LARKIN K. and MARSHALL A. (2008) City-regions: emerging lessons from England. Centre for Cities, London. 
LGA (2006) City Regions and Beyond. Local Government Association, London.

LORD A. (2009) Mind the gap. The theory and practice of state rescaling: Institutional morphology and the 'new' city-regionalism. Space \& Polity 13, 77-92.

LOVERING J. (1995) Creating discourses rather than jobs: the crisis in the cities and the transition fantasies of intellectuals and policy makers, in HEALEY P., CAMERON S., DAVOUDI S., GRAHAM S. and MADANI-POUR A. (Eds.) Managing Cities: The New Urban Context, pp.10926. Wiley, Chichester.

McGUIRK P. (2007) The political construction of the city-region: Notes from Sydney. International Journal of Urban and Regional Research 31, 179-87.

MORGAN K. (2002) The English question: Regional perspectives on a fractured nation. Regional Studies 36, 797-810.

MORGAN K. (2006) The challenge of polycentric planning: Cardiff as a capital city region? Papers in Planning Research 185. Cardiff School of City and Regional Planning, Cardiff.

NLGN (2005) Seeing the Light? Next Steps for City Regions. NLGN, London.

NWDA (2010) Atlantic Gateway. NWDA, Warrington.

NWSG (2004) Moving Forward - The Northern Way. NWSG, Newcastle.

NWSG (2005) Business Plan 2005-08. NWSG, Newcastle.

NWSG (2007) Review of Northern Way Activities. NWSG, Newcastle.

ODPM (2003) Sustainable Communities: Building for the Future. ODPM, London.

ODPM (2004) Making it Happen - The Northern Way. ODPM, London.

ODPM (2005) Planning Glossary. ODPM, London.

ODPM (2006a) A Framework for City-Regions. ODPM, London.

ODPM (2006b) A Framework for City-Regions - Working Paper 2. ODPM, London.

OECD (2007) Competitive Cities in the Global Economy. OECD, Paris. 
PARR J. (2005) Perspectives on the city-region. Regional Studies 39, 555-66.

PERKMANN M. (2007) Construction of new territorial scales: a framework and case study of the EUREGIO cross-border region. Regional Studies 41, 253-66.

REGIONAL POLICY COMMISSION (1996) Renewing the Regions: Strategies for Regional Economic Development. Pavic, Sheffield.

RODRÍGUÉZ-POSE A. and GILL N. (2003) The global trend towards devolution and its implications. Environment and Planning C 21, 331-53.

RUSSELL H. (2008) Research into Multi Area Agreements: Interim Report. CLG, London.

SASSEN S. (1991) The Global City: New York, London, Tokyo. Princeton University Press, Princeton. SCOTT A. (ed.) (2001a) Global City-Regions: Trends, Theory, Policy. Oxford University Press, Oxford. SCOTT A. (2001b) Globalization and the rise of city-regions. European Planning Studies 9, 813-26.

SCOTT A. (1998) Regions and the World Economy: The Coming Shape of Global Production, Competition, and Political Order. Oxford University Press, Oxford.

SCOTT A. (2008) Resurgent metropolis: Economy, society and urbanization in an interconnected world. International Journal of Urban and Regional Research 32, 548-64.

SCOTT A. and STORPER M. (2003) Regions, globalization, development, Regional Studies 37, 579-93. STORPER M. (1997) The Regional World: Territorial Development in a Global Economy. Guildford Press, New York.

STORPER M. and MANVILLE M. (2006) Behaviour, preferences and cities: Urban theory and urban resurgence. Urban Studies 43, 1247-74.

TAYLOR P. (1993) The meaning of the north: England's 'foreign country' within. Political Geography $12,136-55$ 
TEWDWR-JONES M. and MCNEILL D. (2000) The politics of city-region planning and governance. European Urban and Regional Studies 7, 119-34.

UNFPA (2007) State of the World Population. UNFPA, New York.

WORK FOUNDATION (2006) Enabling Cities in the Knowledge Economy. CLG, London.

\footnotetext{
'A notable exception to this rule is Shanghai, where the city and city-region population are equivalent at 18.2 million.

ii Their analysis took in Brazil, Mexico, India, China, the USA, and some European countries.

iii Part of the 2006 Local Government White Paper, the Audit Commission's Comprehensive Area Assessment now allows for cross-border activity to be measured when assessing local authority performance. The first results were due on 10 December, 2009.
}

iv The Northern Way has been discussed at length previously in this journal by GOODCHILD and HICKMAN (2006).

' This has echoes of Peter Taylor's fascinating account of the North as England's 'foreign country' within (TAYLOR, 1993).

vi The Core Cities Group was established in 1995 to lobby central government about the needs of England's eight leading regional cities and increase their profile internationally.

vii Stuart Gulliver is professor of City Development at the University of Glasgow and an internationally recognised practitioner. As Chief Executive of Glasgow Development Agency he contributed to the regeneration of the city of Glasgow and its economy during the 1990s. He was interim Chief Executive of England's first CDC, Creative Sheffield, and lead advisor on the establishment of the Newcastle-Gateshead CDC. 
viii This is Gulliver's attempt to distance CDCs from previous institutions (in particular RDAs) which were greeted with much fanfare, but ultimately powerless to meet expectations.

ix Like the other two cities that were URC pilots in 1999 (Sheffield, Liverpool), Manchester developed its own local response to the need to amplify the geographical coverage of their URC. But while Creative Sheffield and Liverpool Vision were easily captured and branded as CDCs, Manchester Enterprises resisted the government's attempts to capture it and brand it as a CDC this despite being included, alongside Creative Sheffield, as one of two models for CDCs in the consultation (CLG, 2006a).

${ }^{x}$ Furthermore, for Manchester, their MAA was a natural continuation of over twenty years established partnership working at this scale, where following the 1986 abolition of the Greater Manchester County Council by Margaret Thatcher's UK Conservative Government the metropolitan county continues to exist in law and as a geographic frame of reference with several county-wide services co-ordinated through the Association of Greater Manchester Authorities - established in 1986 by the ten district councils of Greater Manchester as a voluntary organisation to develop policy, lobby government and others, and co-ordinate a range of services across the metropolitan area.

${ }^{x i}$ It was exactly this failure on the part of the Labour Government to specify what was on offer when attempting to establish ERAs that led to the failure of their post-1997 regional policy (HARRISON, 2006). 